\title{
To evaluate the efficacy of various types of toothbrush grips used to remove dental plaque by children in age group 3-12 years.
}

\author{
Dr. Ruchi Arora ${ }^{1}$, Dr. Chirag Raiyani ${ }^{2}$, Dr. Deepak Bhayya ${ }^{3}$ \\ ${ }^{1,2}$ (Department of Pedodontics and preventive dentistry, Darshan dental college/RUHS, India) \\ ${ }^{3}$ (Department of Pedodontics and preventive dentistry, Pacific dental college/PAHER, India)
}

\begin{abstract}
Introduction: The guidance given to young children in tooth brushing is important not only for preventing caries and gingivitis but also for teaching young children the concept of oral hygiene, as a first step towards acquiring regular hygienic habits in their daily lives. Aim: To evaluate the tooth brushing ability in children aged 3 to 12 years and its relation to type of grip used, and the duration of brushing. Method: 100 participants including boys and girls aged 3 to 12 years who sought treatment at the Department of Pedodontics and Preventive dentistry, Darshan Dental College - Udaipur were selected. Children were divided in to three groups according to age: 3-6 years, 7-9 years and 10-12 years. We then investigated the association between grip type and plaque removal, using plaque scores obtained before and after brushing. Result: The most common grip used was distal oblique with more efficient plaque removal and Precision grip being the least efficient in all age groups. The statistical data was significant with $p=0.000$ and Mean brushing duration for most children was 2.19 min. Conclusion: Distal oblique grip and less than 2 min duration of brushing has more plaque removal efficacy and there was no significance found in plaque removal among different age group.
\end{abstract}

Keywords: Oral hygiene, Grips, Brushing, Plaque.

\section{Introduction:}

Tooth brushing is the most practical and effective means of achieving and maintaining adequate oral hygiene. Dental plaque being the cause of various dental and periodontal problems must be removed effectively. Only tooth-brushing methods and good dentifrices will not help to remove the dental plaque. Therefore, it is necessary to know the duration and proper toothbrush grip for effective oral hygiene. It is generally believed that toothbrushing is inefficient among children younger than 10 years, perhaps due to lack of motivation and poor manual dexterity, which are normal at this age [1]. In order for the hand tooth brushing to be effective a certain degree of manual dexterity is required. This is especially important in children since the dexterity of the child varies and increases according to his/her age [2].

\section{Aims and Objectives:}

The aims of this study was to evaluate the tooth brushing ability in children aged 3 to 12 years and its relation to types of grip use and the duration of brushing.

\section{Materials and Method}

Hundred participants including boys and girls aged 3-12 years who sought treatment at the Department of Pedodontics and Preventive dentistry, of our institute after obtaining permission from the ethical committee set up by the institute.

\subsection{Materials used:}

Questionnaire forms, Disposable gloves and mouth mask, Mouth mirror, Straight probe, Disclosing Agent, Explorer, Tooth paste, Medium hard, Multitufted, nylon bristled tooth brush, Face mirror.

\subsection{Inclusion criteria:}

(1) Children aged 3-12 years with a quadrant consisting of six teeth in primary, mixed, or permanent dentition. (2) Both males and females were included and (3) Parent consent.

\subsection{Exclusion criteria:}

History of: (1) Neuromuscular disorders (2) Hearing impairment (3) Sight impairment (4) Mental impairment (5) Orthodontic appliances and (6) Temperomandibular joint disorders.

\subsection{Method:}

A total of 100 children were randomly selected from the out-patient in Department of Pedodontics and Preventive dentistry, of our institute. Participating children were asked to avoid tooth brushing in the evening 
and morning before clinical examinations. Children were divided in to three groups according to their age: Group - $1=3-6$ years, Group $-2=7-9$ years and Group $-3=10-12$ years

Each participant was assessed in a random order after taking consent from their parents. A questionnaire was filled and plaque score was recorded according to Silness and Loe in 1964. The participant were asked to brush; the type of grip used and duration of brushing were recorded without the knowledge of the participant. After brushing, again disclosing agent was applied and plaque score was recorded. The manual dexterity of the children was evaluated according to Beals et al [3]. (Distal Oblique, Oblique, Precision, Power, Spoon).

\section{Statistical Analysis:}

The Statistical Package for Social Sciences (SPSS) Version 15.0 and ANOVA test were used to analyze the data.

\section{Results:}

Among the 100 participant children most common grip used was distal oblique with more efficient plaque removal with 0.5665 as mean value and Precision grip being the least efficient [Table 1]. There was significance difference between grips and plaque removal efficacy [Table 2]. Plaque removal efficacy was on higher side in the subjects brushing for less than $2 \mathrm{~min}$ with 0.5715 mean [Table 3] and the result was significant between the group and within the group [Table 4]. There was no mean difference between age groups and plaque removal efficacy [Table 5] and there was no Statistical significance found in plaque removal among different age group [Table 6]. The mean brushing time was $2.19 \mathrm{~min}$ in 100 uninstructed participate [Table 7]. Pie chart showing distribution of difference types of brushing technique with highest being Horizontal method followed by vertical and horizontal /vertical. [Chart 1].

TABLE 1: Various grips and plaque removal efficacy

\begin{tabular}{|c|c|c|c|c|c|c|c|c|}
\hline \multirow[t]{2}{*}{ Grips } & \multirow[t]{2}{*}{$\mathbf{N}$} & \multirow[t]{2}{*}{ Mean } & \multirow[t]{2}{*}{$\begin{array}{c}\text { Std.Deviatio } \\
n\end{array}$} & \multirow[t]{2}{*}{ Std. Error } & \multicolumn{2}{|c|}{$\begin{array}{l}\text { 95\% Confidence } \\
\text { Interval for Mean }\end{array}$} & \multirow[t]{2}{*}{ Min } & \multirow[t]{2}{*}{ Max } \\
\hline & & & & & Lower & Upper & & \\
\hline Oblique & 23 & 0.4804 & 0.17259 & 0.03599 & 0.4058 & 0.5551 & 0.25 & 0.83 \\
\hline Spoon & 11 & 0.3409 & 0.11606 & 0.03499 & 0.2629 & 0.4189 & 0.21 & 0.49 \\
\hline Precision & 9 & 0.3122 & 0.13386 & 0.04462 & 0.2093 & 0.4151 & 0.10 & 0.43 \\
\hline Distal Oblique & 34 & 0.5665 & 0.21601 & 0.03705 & 0.4911 & 0.6418 & 0.25 & 1.09 \\
\hline Power & 23 & 0.4596 & 0.10494 & 0.02188 & 0.4142 & 0.5049 & 0.23 & 0.66 \\
\hline Total & 100 & 0.4744 & 0.18647 & 0.01865 & 0.4374 & 0.5114 & 0.10 & 1.09 \\
\hline
\end{tabular}

TABLE 2: Significance difference between groups and within groups

\begin{tabular}{|c|c|c|c|c|c|}
\hline & $\begin{array}{c}\text { Sum of } \\
\text { Squares }\end{array}$ & df & Mean Square & F & Sig. \\
\hline Between Groups & 0.727 & 4 & 0.182 & 6.357 & $\mathbf{0 . 0 0 0}$ \\
\hline Within Groups & 2.715 & 95 & 0.029 & & \\
\hline Total & 3.442 & 99 & & & \\
\hline
\end{tabular}

TABLE 3: Duration and plaque removal efficacy

\begin{tabular}{|c|c|c|c|c|c|c|c|c|}
\hline \multirow[t]{2}{*}{ Duration } & \multirow[t]{2}{*}{$\mathbf{N}$} & \multirow[t]{2}{*}{ Mean } & \multirow[t]{2}{*}{$\begin{array}{c}\text { Std. } \\
\text { Deviation }\end{array}$} & \multirow[t]{2}{*}{ Std. Error } & \multicolumn{2}{|c|}{$\begin{array}{l}\text { 95\% Confidence } \\
\text { Interval for Mean }\end{array}$} & \multirow[t]{2}{*}{ Min } & \multirow[t]{2}{*}{ Max } \\
\hline & & & & & Lower & Upper & & \\
\hline $2 \mathrm{~min}$ & 1 & 0.4300 &. &. &. &. & 0.43 & 0.43 \\
\hline$>2 \min$ & 59 & 0.4093 & 0.15368 & 0.02001 & 0.3693 & 0.4494 & 0.10 & 0.84 \\
\hline Total & 100 & 0.4744 & 0.18647 & 0.01865 & 0.4374 & 0.5114 & 0.10 & 1.09 \\
\hline
\end{tabular}

TABLE 4: Significance difference between groups and within groups

\begin{tabular}{|c|c|c|c|c|c|}
\hline & $\begin{array}{c}\text { Sum of } \\
\text { Squares }\end{array}$ & df & Mean Square & F & Sig. \\
\hline Between Groups & 0.629 & 2 & 0.314 & 10.843 & $\mathbf{0 . 0 0 0}$ \\
\hline Within Groups & 2.813 & 97 & 0.029 & & \\
\hline Total & 3.442 & 99 & & & \\
\hline
\end{tabular}


TABLE 5: Age groups and plaque removal efficacy

\begin{tabular}{|c|c|c|c|c|c|c|c|c|}
\hline Age & N & Mean & \multirow{2}{*}{$\begin{array}{c}\text { Std. } \\
\text { Deviation }\end{array}$} & \multirow{2}{*}{ Std. Error } & \multicolumn{2}{|c|}{$\begin{array}{c}\text { 95\% Confidence } \\
\text { Interval for Mean }\end{array}$} & \multirow{2}{*}{ Min } & \multirow{2}{*}{ Max } \\
\cline { 5 - 8 } & & & & & Lower & Upper & & \\
\hline 3 to 6 & 30 & 0.4287 & 0.14095 & 0.02573 & 0.3760 & 0.4813 & 0.25 & 0.78 \\
\hline 7 to 9 & 30 & 0.4967 & 0.22423 & 0.04094 & 0.4129 & 0.5804 & 0.21 & 1.09 \\
\hline 10 to12 & 40 & 0.4920 & 0.18384 & 0.02907 & 0.4332 & 0.5508 & 0.10 & 0.83 \\
\hline Total & 100 & 0.4744 & 0.18647 & 0.01865 & 0.4374 & 0.5114 & 0.10 & 1.09 \\
\hline
\end{tabular}

TABLE 6: Significance difference between groups and within groups

\begin{tabular}{|c|c|c|c|c|c|}
\hline & $\begin{array}{c}\text { Sum of } \\
\text { Squares }\end{array}$ & df & Mean Square & F & Sig. \\
\hline Between Groups & 0.090 & 2 & 0.045 & 1.302 & $\mathbf{0 . 2 7 7}$ \\
\hline Within Groups & 3.352 & 97 & 0.035 & & \\
\hline Total & 3.442 & 99 & & & \\
\hline
\end{tabular}

TABLE 7: Mean duration at different age

\begin{tabular}{|c|c|c|c|c|c|c|c|c|}
\hline \multirow[t]{2}{*}{ Age } & \multirow[t]{2}{*}{$\mathbf{N}$} & \multirow[t]{2}{*}{ Mean } & \multirow[t]{2}{*}{$\begin{array}{c}\text { Std. } \\
\text { Deviation }\end{array}$} & \multirow[t]{2}{*}{ Std. Error } & \multicolumn{2}{|c|}{$\begin{array}{l}\text { 95\% Confidence } \\
\text { Interval for Mean }\end{array}$} & \multirow[t]{2}{*}{ Min } & \multirow[t]{2}{*}{ Max } \\
\hline & & & & & Lower & Upper & & \\
\hline 3 to 6 & 30 & 2.20 & 0.997 & 0.182 & 1.83 & 2.57 & 1 & 3 \\
\hline 7 to 9 & 30 & 2.37 & 0.928 & 0.169 & 2.02 & 2.71 & 1 & 3 \\
\hline 10 to 12 & 40 & 2.05 & 1.011 & 0.160 & 1.73 & 2.37 & 1 & 3 \\
\hline Total & 100 & 2.19 & 0.982 & 0.098 & 2.00 & 2.38 & 1 & 3 \\
\hline
\end{tabular}

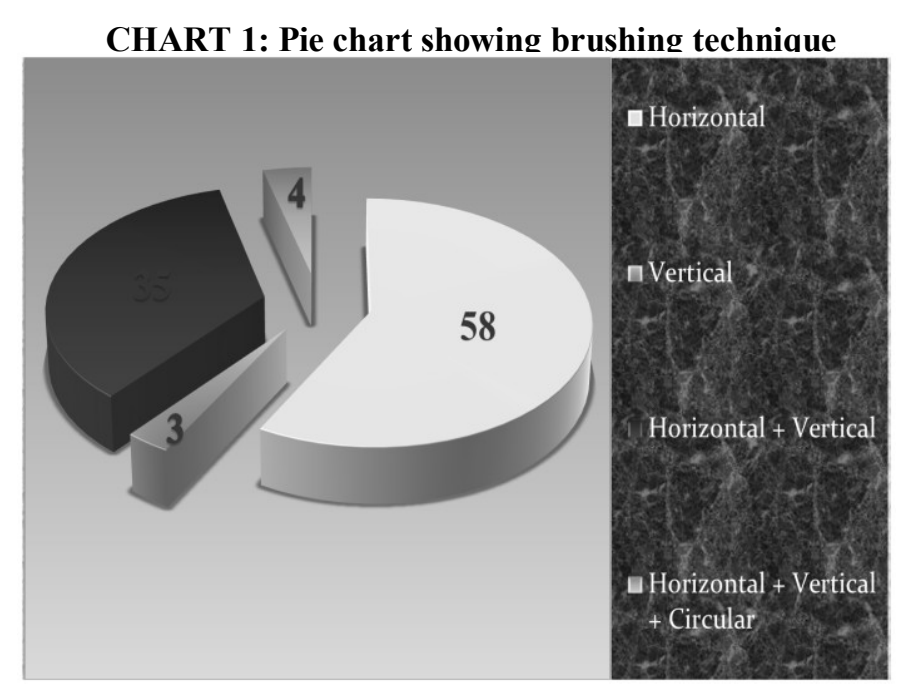

\section{Discussion:}

It is logical to assume that the more efficient the brushing technique, the better the effectiveness of plaque removal from the tooth surfaces. In this study, the most common grip used was distal oblique which was found to be most efficient in plaque removal. This finding is similar to the study which was conducted by Beals et al. [3], Mentes and Atukeren [4] and Sharma et al [5]. Macgregor and Rugg-Gunn, [6] found that overall brushing time was 1.3 min in 85 uninstructed children aged 11-13 years. Das UM and Singhal P, [7] reported a mean brushing time of 1.27 min among children aged 9-11 years. In the present study, overall brushing time was $2.19 \mathrm{~min}$ and the plaque efficacy was found to be more in children who brush their teeth less then 2 min. Various tooth brushing techniques (horizontal, vertical, and/or circular) are used by the children but most children brushed their teeth with horizontal scrubbing. Several studies $[6,8,9]$ reported that horizontal scrubbing was the method of choice among young children and that they were unable to use other tooth brushing methods.

\section{Conclusion:}

Distal oblique grip and less than 2 min duration of brushing has more plaque removal efficacy. There was no statistically significance difference between age group and the plaque removal efficacy. Further studies with larger sample sizes are needed to establish a relationship between grip and effective plaque removal. 


\section{References:}

[1] Grossman E, Proskin HA. Comparison of the efficacy and safety of an electric and a manual children's toothbrush. J Am Dent Assoc, 128,1997,469-474.

[2] G.A.Van der Weijden et al. Relationship between the plaque removal efficacy of a manual tooth brush and brushing force. J Clin Periodontol, 25,1998,413-416.

[3] Beals D, Wong-Paredes M, Allen B, Rutter B, Stegemen J. Grip architecture in manual toothbrushing. J Dent Res, 78,1999, 413.

[4] Mentes A, Atukeren J. A study of manual toothbrushing skills in children aged 3 to 11 years. J Clin Pediatr Dent ,27,2002,91-94.

[5] Sharma S, Yeluri R, Jain A and Munshi A. Effect of toothbrush grip on plaque removal during manual toothbrushing in children. Journal of Oral Science,54,(2), 2012,183-190.

[6] Rugg-Gunn AJ, Macgregor ID. A survey of toothbrushing behavior in children and young adults. J Periodontal Res,13,1978,382389.

[7] Das UM, Singhal P. Tooth brushing skills for the children aged 3-11 years. J Indian Soc Pedod Prev Dent,27,2009,104-107.

[8] Kimmelman BB, Tassman GL. Research in design of children's toothbrushes. J Dent Child, 27,1960,60-64.

[9] McClure DB. A comparison of toothbrushing technics for the preschool child. J Dent Child, 33,1966,205-210. 